\title{
MICROSTRUCTURE AND MECHANICAL PROPERTIES OF OXIDE DISPERSION STRENGTHENED HIGH-ENTROPY ALLOYS CoCrFeMnNi AND $\mathrm{CrFe}_{2} \mathrm{MnNi}$
}

\author{
I.V. Kolodiy ${ }^{1}$, O.M. Velikodnyi ${ }^{1}$, M.A. Tikhonovsky ${ }^{1}$, V.N. Voyevodin ${ }^{1,2}$, O.S. Kalchenko ${ }^{1}$, \\ R.L. Vasilenko ${ }^{1}$, V.S. Okovit ${ }^{1}$ \\ ${ }^{1}$ National Science Center "Kharkov Institute of Physics and Technology”, Kharkiv, Ukraine; \\ ${ }^{2}$ V.N. Karazin Kharkiv National University, Kharkiv, Ukraine \\ E-mail: kolodiy@kipt.kharkov.ua
}

High-entropy alloys (HEAs) $\mathrm{CoCrFeMnNi}$ and $\mathrm{CrFe}_{2} \mathrm{MnNi}$, dispersion-strengthened by pre-synthesized nanooxides composition of $80 \% \mathrm{Y}_{2} \mathrm{O}_{3}+20 \% \mathrm{ZrO}_{2}$ (mol.\%) were obtained by mechanical alloying followed by compaction and sintering. Average grain size of the oxide dispersion-strengthened (ODS) alloys was about $2 \mu \mathrm{m}$. Oxide precipitates in alloys are characterized by the presence of small particles with an average size of about $10 \mathrm{~nm}$ and a density of $\approx 10^{21} \mathrm{~m}^{-3}$, as well as small amount of larger particles sizes of $50 \ldots 150 \mathrm{~nm}$. The qualitative composition of particles of different sizes has been established. Mechanical properties of HEAs were studied at different temperatures. It is shown that strengthening of the studied alloys by nanooxide particles leads to a significant increase in strength characteristics.

Development of the next generation nuclear reactors imposes increased requirements on structural materials. So an actual problem of reactor materials science is the development of novel class of high-performance structural materials with high radiation resistance and improved mechanical and corrosion characteristics. Oxide dispersion-strengthened (ODS) ferriticmartensitic and austenitic steels [1-7], which can be used up to damaging doses above $180 \mathrm{dpa}$, are considered as promising structural materials for nuclear energy applications. But recent theoretical research activities and previous experimental results show that so-called high-entropy alloys (HEAs) [8, 9] are the other promising class of radiation-resistant materials. Typically HEAs contain four, five or more elements with equal or close concentrations. Entropy of mixing increases significantly with a large number of elements in the alloys and their high concentration, which contributes to the formation of substitutional solid solutions [8]. HEAs are characterized by strong lattice distortion caused by the difference in atomic radii of dissolved elements, which affects the solid-solution hardening [10], as well as sluggish diffusion, as vacancies associated with atoms of dissolved elements form stable "atom-vacancy" complexes [11]. Some HEAs show attractive mechanical properties for practical usage. Exactly because of this reason HEAs are considered as a promising material for structural applications both at cryogenic and elevated temperatures [12, 13].

Research of HEAs is mainly focused on single-phase solid solutions with simple crystal lattices - FCC [9] or BCC [14]. Classic HEA CoCrFeMnNi [9] attracted a lot of attention as one of the most promising material in terms of mechanical properties, especially at cryogenic temperatures $[15,16]$. The strength of this alloy was increased both by thermal-mechanical treatment [17] and by a more complex method - gas-atomized powder was processed by mechanical milling and spark plasma sintering [18]. The use of planetary high-energy milling $[19,20]$ followed by spark plasma sintering also leads to a significant increase in the strength of the alloy, but at the same time plasticity decreases. Also there are other approaches to increase strength of HEAs.

In this work we used approach [21] that proved itself in creation of oxide dispersion-strengthrned steels [6, 7], namely, strengthening of HEAs by thermodynamically and radiation-resistant nanooxides by mechanical alloying and followed compaction and sintering. Exactly this approach can be considered as an alternative to optimize the composition and microstructure of existing austenitic or ferriticmartensitic steels [22-24].

Therefore the aim of this work is to study the structure and mechanical properties of ODS HEAs mechanically alloyed by nanooxides of $\mathrm{Y}_{2} \mathrm{O}_{3}-\mathrm{ZrO}_{2}$ system. Moreover, for the study we chose alloys, the behavior of which had been previously studied under radiation exposure [25] and under corrosion in molten lead [26].

\section{MATERIALS AND METHODS}

The research was carried out on two compositions of HEAs with different element contents (atomic percentages are indicated) - classic five-component Cantor alloy CoCrFeMnNi (E3), as well as cobalt-free four-component alloy $\mathrm{CrFe}_{2} \mathrm{MnNi}$ (E32). The absence of cobalt in E32 alloy is important for its possible application in conditions of radioactive exposure, since cobalt has high induced activity and very long half-life. The alloys were obtained by arc melting with a nonconsumable tungsten electrode in pure argon. The purity of initial components was not less than 99.9\%. To ensure homogeneity ingots were remelted at least 5 times, the size of ingots was $6 \times 15 \times 60 \mathrm{~mm}$. Powders of HEA were obtained by mechanical grinding using abrasives, and then powders were sieved into fractions. Powders with close to equiaxial shape and less than 
$300 \mu \mathrm{m}$ in size were used for further operations. Oxide dispersion strengthening was carried out by mechanical alloying. $0.5 \mathrm{wt} \%$ of pre-synthesized nanopowders composition of $80 \% \mathrm{Y}_{2} \mathrm{O}_{3}+20 \% \mathrm{ZrO}_{2}(\mathrm{~mol} . \%)$ were used as alloying components. The synthesized powders had cubic structure with lattice parameter $a=10.2 \AA$, average size was about $17 \mathrm{~nm}$.

Mechanical alloying of HEA with nanooxides was performed by high-energy planetary ball-milling in argon inert atmosphere. Milling time in most experiments was $4 \mathrm{~h}$. Other parameters of the milling process are similar to those used in [7]. Obtained powder consisted of agglomerated particles with multimodal distribution and significant size variations (from few microns to $500 \mu \mathrm{m}$ and more). Subsequently a fraction with size of $<300 \mu \mathrm{m}$ was used in the work. All mechanical processing operations, from powders pressing (compacting) to compact billet rolling, were carried out at room temperature. Wherein, mechanical treatments were alternated with short-term annealing (sintering) in vacuum at $1373 \mathrm{~K}$. As a result tapes of ODS HEAs $200 \mu \mathrm{m}$ thickness were obtained. The same tapes were obtained by rolling the original as-cast and homogenized at $1373 \mathrm{~K}$ blanks of both alloys. Before preparation for structural studies and tensile tests samples were finally annealed at $1273 \mathrm{~K}$ to relieve stresses and form the final microstructure.

Mechanical tests were carried out under active tension at a rate of $10^{-3} \mathrm{~s}^{-1}$ on flat dumbbell shaped specimens with the dimensions of the working section $0.2 \times 1.0 \times 6 \mathrm{~mm}$, cut by the electric spark method from tapes in the rolling direction. Microstructural studies were carried out on metallographic inversion microscope Olympus GX51 and scanning electron microscope JSM 7001F equipped with the system for energy-dispersive X-ray spectroscopy INCA ENERGY 350. The fine structure of samples was studied on transmission electron microscope JEM-2100 (accelerating voltage $200 \mathrm{kV}$ ) equipped with scanning attachment BF-STEM JEOL EM-24511 and energy-

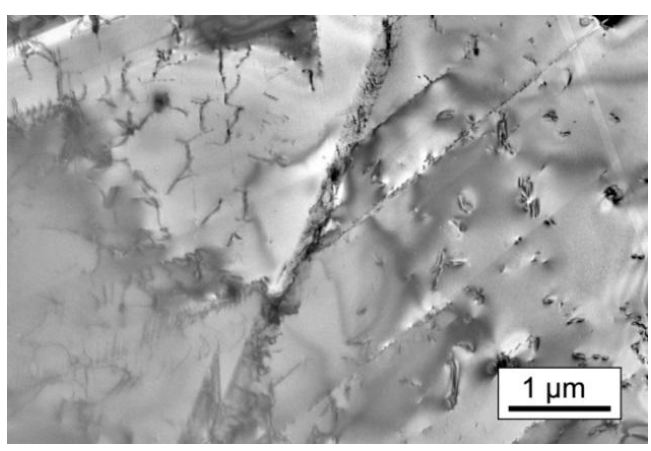

E3 dispersive X-ray microanalyzer JEOL EX-24063 JGP. $\mathrm{X}$-ray diffraction study was carried out using DRON-407 diffractometer in Bragg-Brentano geometry using $\mathrm{Cu}-\mathrm{K} \alpha$ radiation and scintillation detector.

\section{RESULTS AND DISCUSSION}

In the initial as-cast state ingot of five-component HEA CoCrFeNiMn has dendritic structure. Dendritic regions are enriched in $\mathrm{Co}, \mathrm{Cr}$, and $\mathrm{Fe}$ and have reduced content of $\mathrm{Mn}$ and $\mathrm{Ni}$ (Table 1). The ingot of the fourcomponent $\mathrm{CrFe}_{2} \mathrm{MnNi}$ HEA does not have a pronounced dendritic structure. Results on elemental analysis of different structural elements for both HEAs are given in Table 1.

Table 1

Chemical composition (at.\%) of as-cast alloys E3 and E32

\begin{tabular}{|l|c|c|c|c|c|}
\hline \multicolumn{1}{|c|}{ Elements } & $\mathrm{Co}$ & $\mathrm{Cr}$ & $\mathrm{Fe}$ & $\mathrm{Ni}$ & $\mathrm{Mn}$ \\
\hline Alloy & \multicolumn{6}{|c|}{$\mathrm{E} 3(20 \mathrm{Co}-20 \mathrm{Cr}-20 \mathrm{Fe}-20 \mathrm{Mn}-20 \mathrm{Ni})$} \\
\hline $\begin{array}{l}\text { Actual } \\
\text { composition }\end{array}$ & 19.4 & 20.9 & 21.2 & 19.1 & 19.4 \\
\hline Dendrites & 21.0 & 21.8 & 22.1 & 16.7 & 16.4 \\
\hline $\begin{array}{l}\text { Interdendritic } \\
\text { space }\end{array}$ & 16.8 & 17.0 & 16.7 & 22.9 & 26.6 \\
\hline Alloy & \multicolumn{6}{|c|}{$\mathrm{E} 32(20 \mathrm{Cr}-40 \mathrm{Fe}-20 \mathrm{Mn}-20 \mathrm{Ni})$} \\
\hline $\begin{array}{l}\text { Actual } \\
\text { composition }\end{array}$ & - & 19.1 & 41 & 19.8 & 20.1 \\
\hline
\end{tabular}

Homogenizing annealing at $1373 \mathrm{~K}$ led to the disappearance of the dendritic structure, and the grain composition was close on average to the composition of the as-cast ingot. Further ingots were rolled at room temperature with intermediate annealing at $1373 \mathrm{~K}$ and final annealing at $1273 \mathrm{~K}$. Microstructure of the studied alloys after thermal treatment is shown in Fig. 1. As it can be seen, final annealing at $1273 \mathrm{~K}$ led to the formation of the grain structure with an average grain size of more than $10 \mu \mathrm{m}$. In case of alloy E3 some amount of annealing twins and dislocations is observed, whereas in alloy E32 they are almost absent.

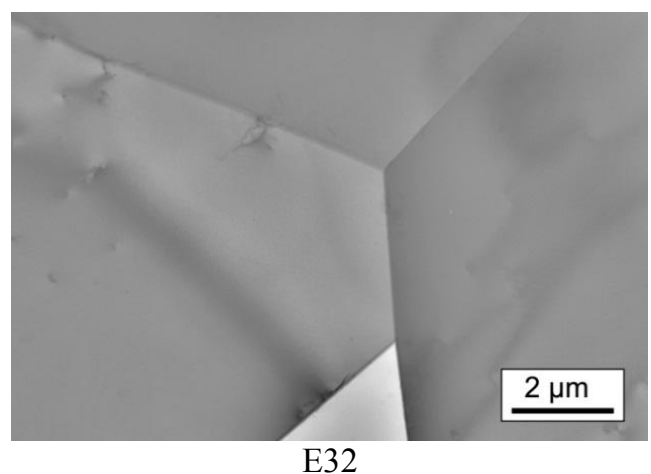

E32

Fig. 1. Grain microstructure of alloys E3 and E32 annealed at $1273 \mathrm{~K}$ for 1 hour

Next investigated HEAs were subjected to dispersion strengthening by $\mathrm{Y}_{2} \mathrm{O}_{3}-\mathrm{ZrO}_{2}$ nanooxides. Main parameters for the radiation resistance of ODS HEAs are the structural-phase state, the size and density of oxide precipitates, the composition of oxides and the state of the "matrix-oxide" interface. The presence of elements that can bind oxygen (e.g. $\mathrm{Cr}, \mathrm{Mn}$ ) in alloys composition also plays significant role on structure formation and properties of ODS HEAs. Microstructure of ODS HEA E3 after final annealing at $1273 \mathrm{~K}$ is shown in Fig. 2. The microstructure is characterized by fine grains (see Fig. 2,a) and precipitates of two types (see Fig. 2,b). First of all, these are large particles size of $50 \ldots 150 \mathrm{~nm}$. In areas of their accumulation mainly small subgrains are observed. Such large particles are present both at the boundaries and inside the grains. The second type of precipitates is small particles size of $\sim 10 \mathrm{~nm}$ and density up to $\sim 10^{21} \mathrm{~m}^{-3}$ (see Fig. 2,b). 


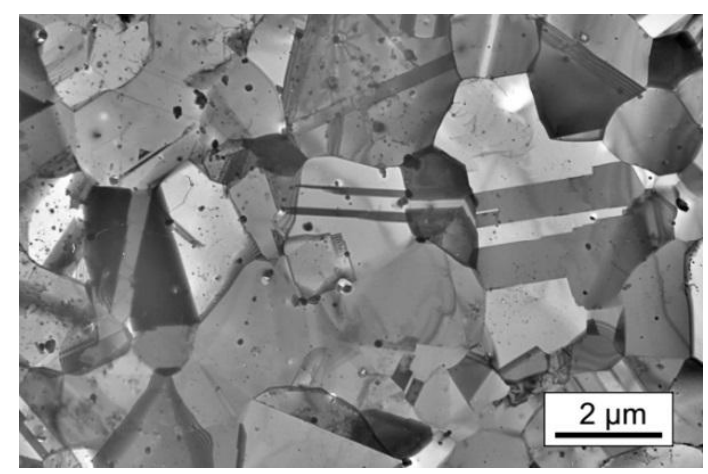

$a$

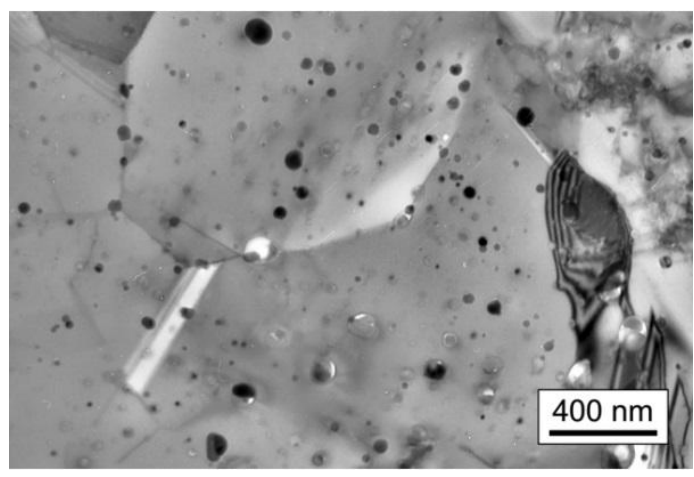

$b$

Fig. 2. Microstructure of ODS HEA E3 types after final annealing at $1273 \mathrm{~K}$ for $1 \mathrm{~h}$

After final annealing grain boundaries became clear and it can be seen that their growth is limited by precipitates. In areas of precipitates accumulation the grain size is $\leq 1 \mu \mathrm{m}$, while in areas with a smaller number of precipitates the grain size reaches $5 \mu \mathrm{m}$. It should be noted that there is a significant number of annealing twins (see Fig. 2,a) in the microstructure of

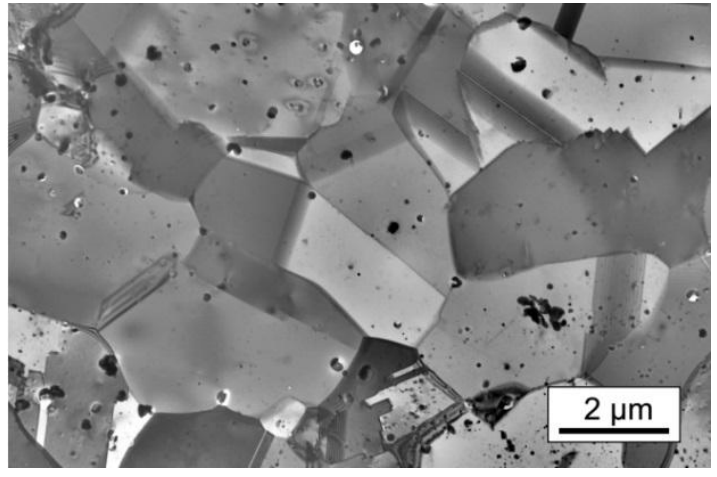

$a$
ODS alloy E3, as in the strips of "pure", i.e. ordinary E3 alloy (see Fig. 1).

Microstructure of the ODS HEA E32 (Fig. 3) after final annealing at $1273 \mathrm{~K}$ is similar to the microstructure of the ODS HEA E3. It also contains precipitates of various sizes.

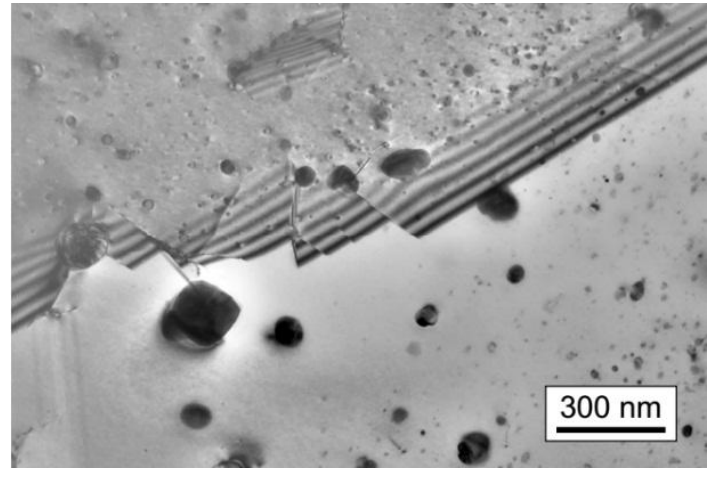

$b$

Fig. 3. Microstructure of ODS HEA E32 types after final annealing at $1273 \mathrm{~K}$ for $1 \mathrm{~h}$

First of all, these are large precipitates up to $150 \mathrm{~nm}$ in size, which are present after annealing at both temperatures. These large particles are present both inside the grains body and at the boundaries. In addition to a small number of medium size precipitates (up to $50 \mathrm{~nm}$ ) there is significant number of small precipitates size of about $10 \mathrm{~nm}$ and density of $\sim 10^{21} \mathrm{~m}^{-3}$. A characteristic feature of both ODS alloys is the uneven volume distribution of oxide precipitates, which is clearly shown in Figs. 2, 3. Also note the absence or small amount of small precipitates in areas around the large precipitates (see Fig. 3,b). That is, in this local areas all oxygen atoms are spent on "building" this type of oxide precipitate.

To determine the type of precipitates the elements distribution in the matrix and precipitates was studied (Fig. 4).

Uniform distribution of the main elements is observed throughout the entire volume of the matrix.
The composition of precipitates was different. Some precipitates are practically free of $\mathrm{Fe}$ and $\mathrm{Ni}$, while others are characterized by significant amounts of $\mathrm{Cr}$ and $\mathrm{Mn}$. Most of the precipitates contain a significant content of yttrium and zirconium, as well as austenitic steel, which was strengthened by the same nanooxides of the $\mathrm{Y}-\mathrm{Zr}-\mathrm{O}$ system [7]. But it is also seen that $\mathrm{Y}$ and $\mathrm{Zr}$ based oxides precipitates correlate with an increase in the intensity of $\mathrm{Cr}$ and $\mathrm{Mn}$, indicating the multicomponent composition of these oxides (or mixing of several oxides in one precipitate, i.e. one type of oxide can be a "substrate" for the growth of oxide of another composition). Moreover, this is typical for oxides of various sizes.

XRD analysis was performed on the tapes of initial and ODS HEAs after final annealing at $T=1273 \mathrm{~K}$ for $1 \mathrm{~h}$. Corresponding diffraction patterns of the samples are shown in Fig. 5. 

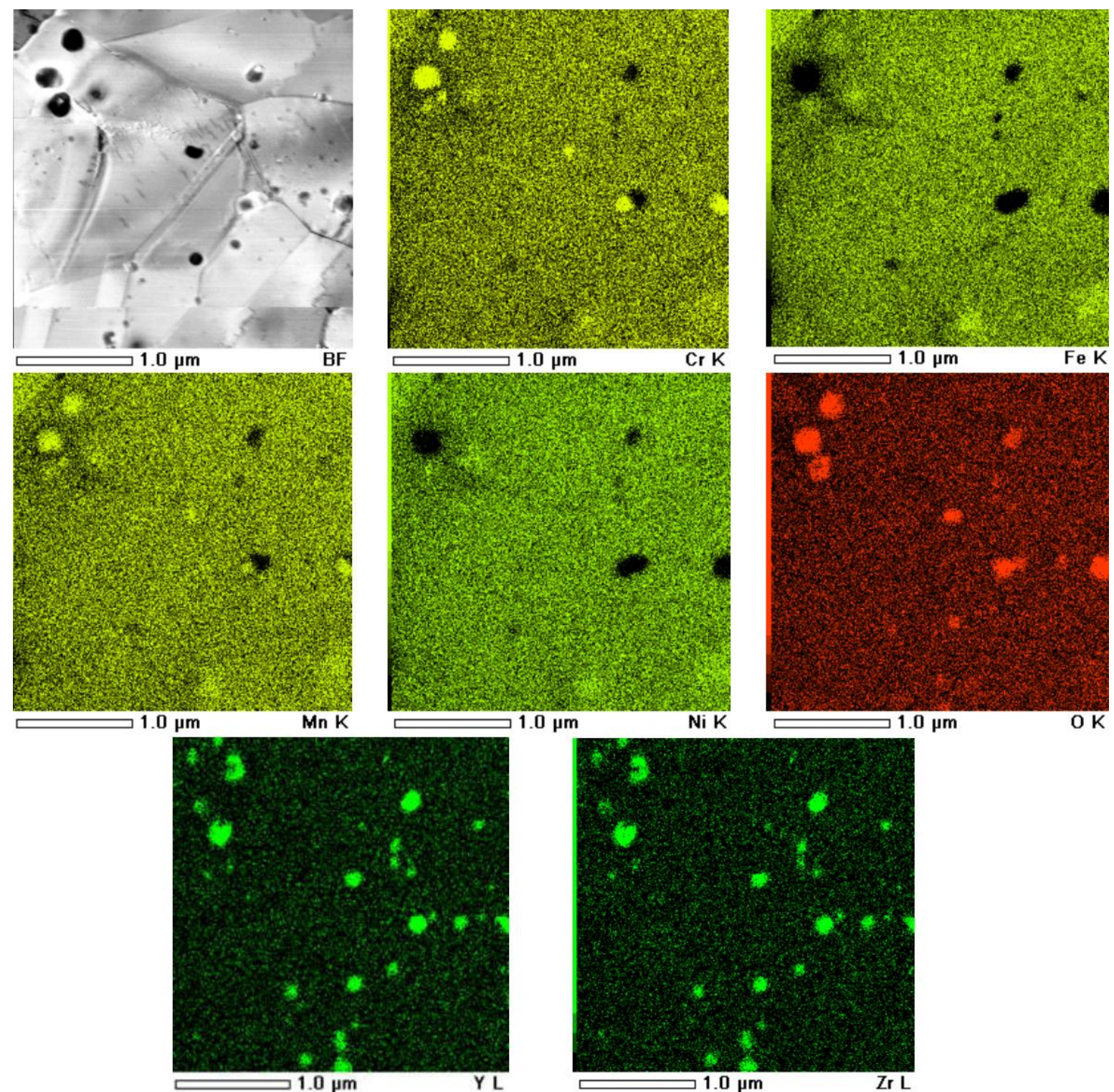

Fig. 4. Distribution of elements in the matrix and precipitates of the ODS HEA E32
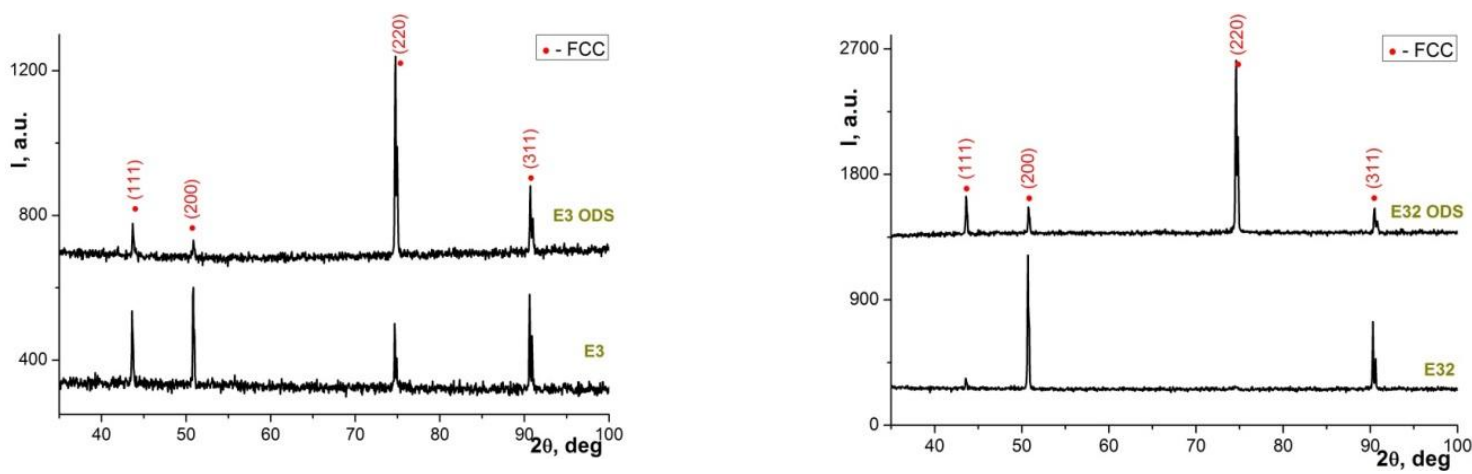

Fig. 5. Diffraction patterns of studied alloys

According to XRD data all samples are single-phase (within the sensitivity of the method) and consist of FCC phase. Thus, for the initial alloys the lattice parameters of the FCC phase are: $a=(3.5943 \pm 3) \cdot 10^{-4}$ and $a=\left(3.6038 \pm 3 \cdot 10^{-4}\right) \AA$, for E3 and E32, respectively. For ODS HEAs E3 and E32 lattice parameters of FCC phase are: $a=(3.5932 \pm 3) \cdot 10^{-4}$ and $a=(3.5994 \pm 3) \cdot 10^{-4} \AA$, respectively. As can be seen, the lattice parameter of the
FCC phase in E32 alloy is greater than the value for the E3 alloy (as well as for initial and ODS). This is due to the replacement of cobalt in E32 alloys with iron, the atomic radius of which is larger than that of cobalt. Also it should be noted that the lattice parameters of the ODS alloys are less than the corresponding values of the initial alloys. This can be explained by the decrease in the content of elements with a large atomic radius $(\mathrm{Cr}$ 
and $\mathrm{Mn}$ ) in the alloys matrix as a result of the formation of complex oxides, which is consistent with the results of the preliminary analysis (see Fig. 4). Diffraction peaks of all alloys are narrow, which indicates the coarse-grained structure of the samples (grain size is more than $1 \mu \mathrm{m}$ ). The distribution of peaks intensities in the diffraction patterns indicates the presence of texture in the samples; moreover, the texture is significantly different in the tapes of initial and ODS alloys. Thus, for ODS alloys the intensity of peaks (220) is significantly overestimated, i.e. in these alloys there is preferred

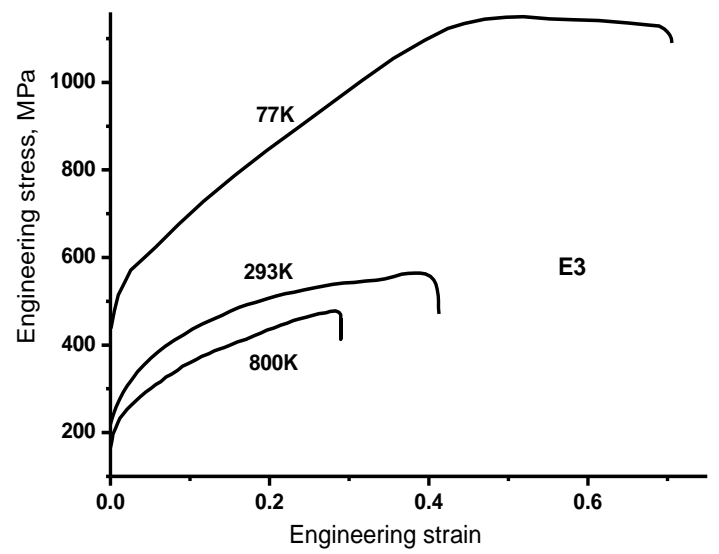

orientation of grains by crystallographic planes (220) parallel to the sample surface. For the initial alloys the intensity of peaks (200) and (311) is overestimated, i.e. the texture is more complex in these samples. Additional research is needed to determine the reasons for this difference.

We also studied the mechanical properties of all obtained high-entropy alloys. Typical stress-strain diagrams of five-component high-entropy alloys E3 and ODS E3 at different temperatures are shown in Fig. 6.

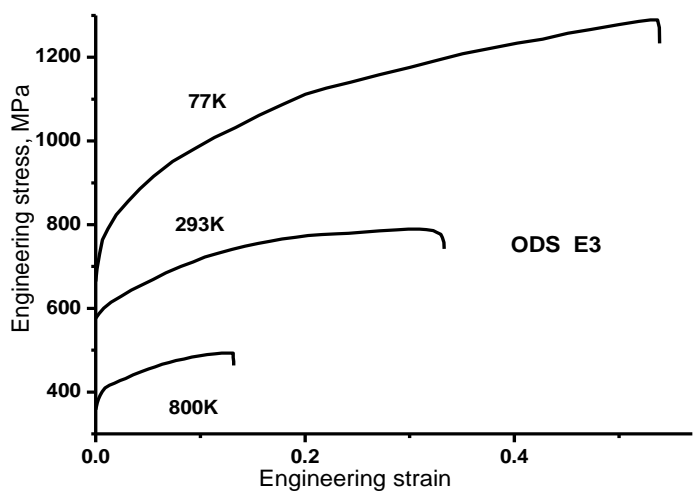

Fig. 6. Stress-strain diagrams of five-component high-entropy alloys E3 and ODS E3 at different temperatures

Determined values of yield strength $\left(\sigma_{0.2}\right)$, tensile strength $\left(\sigma_{\mathrm{B}}\right)$ and uniform elongation to failure $(\delta)$ at different temperatures are presented in Table 2. The deformation curves of E3 and ODS E3 alloys show a significant ability to deformation hardening (especially alloy E3) and high ductility. The maximum values of the yield strength, tensile strength and elongation to failure for alloys E3 and ODS E3 are observed at a temperature of 77 and decrease as the test temperature increases. Exactly at $77 \mathrm{~K}$ deformation is accompanied not only by planar slip of dislocations but also by nanoscale twinning, which contributes to strain hardening and plasticity increasing [16]. For the ODS E3 alloy the strain hardening is noticeably lower, which indicates the effect of oxide precipitates on the twinning process.

As can be seen after oxide dispersion strengthening there is a significant increase in the yield strength by more than 2 times for ODS E3 alloy. At the same time the tensile strength increases slightly. As expected, oxide dispersion strengthening leads to a significant decrease in ductility, but it remains at a sufficient technological level (up to $13 \%$ even at $800 \mathrm{~K}$ ).

Table 2

Mechanical properties of E3 and ODS E3 HEAs at different temperatures

\begin{tabular}{|c|c|c|c|c|c|c|c|c|c|}
\hline \multirow{3}{*}{ Alloy } & \multicolumn{3}{|c|}{$\sigma_{0.2}, \mathrm{MPa}$} & \multicolumn{3}{|c|}{$\sigma_{\mathrm{B}}, \mathrm{MPa}$} & \multicolumn{3}{|c|}{$\delta, \%$} \\
\hline & \multicolumn{9}{|c|}{ Test temperature } \\
\hline & $77 \mathrm{~K}$ & $293 \mathrm{~K}$ & $800 \mathrm{~K}$ & $77 \mathrm{~K}$ & $293 \mathrm{~K}$ & $800 \mathrm{~K}$ & $77 \mathrm{~K}$ & $293 \mathrm{~K}$ & $800 \mathrm{~K}$ \\
\hline E3 & 437 & 221 & 166 & 1150 & 565 & 478 & 71 & 41.5 & 29 \\
\hline ODS E3 & 664 & 576 & 358 & 1289 & 789 & 493 & 54 & 33 & 13 \\
\hline
\end{tabular}

Stress-strain diagrams of non-cobalt high-entropy alloys E32 and ODS E32 at different temperatures are shown in Fig. 6. Determined values of yield strength $\left(\sigma_{0.2}\right)$, tensile strength $\left(\sigma_{\mathrm{B}}\right)$ and uniform elongation to failure $(\delta)$ at different temperatures are presented in Table 3. The deformation curves of E32 and ODS E32 alloys at $77 \mathrm{~K}$ also show a significant deformation hardening and high ductility. Probably, as in the E3 alloy nanoscale twinning contributes to the deformation hardening and ductility increasing.

The yield strength for alloy E32 at $77 \mathrm{~K}$ was lower by $12 \%$ than that in alloy E3. Under equal conditions this reduction can be attributed to the solidsolution hardening. After oxide dispersion strengthening significant increase in the yield strength at 293 and $973 \mathrm{~K}$ is observed for the alloy ODS E32 (almost 2.5 times). There was also a noticeable increase in tensile strength (1.5 times). Similar to the ODS E3 alloy the ductility of the non-cobalt ODS E32 decreased at the maximum test temperature $(973 \mathrm{~K})$ down to $12 \%$. Thus, mechanical properties of the non-cobalt ODS E32 and the fivecomponent ODS E3 alloys are quite close, which allows to prefer the first one, because Co has high induced activity after irradiation. 

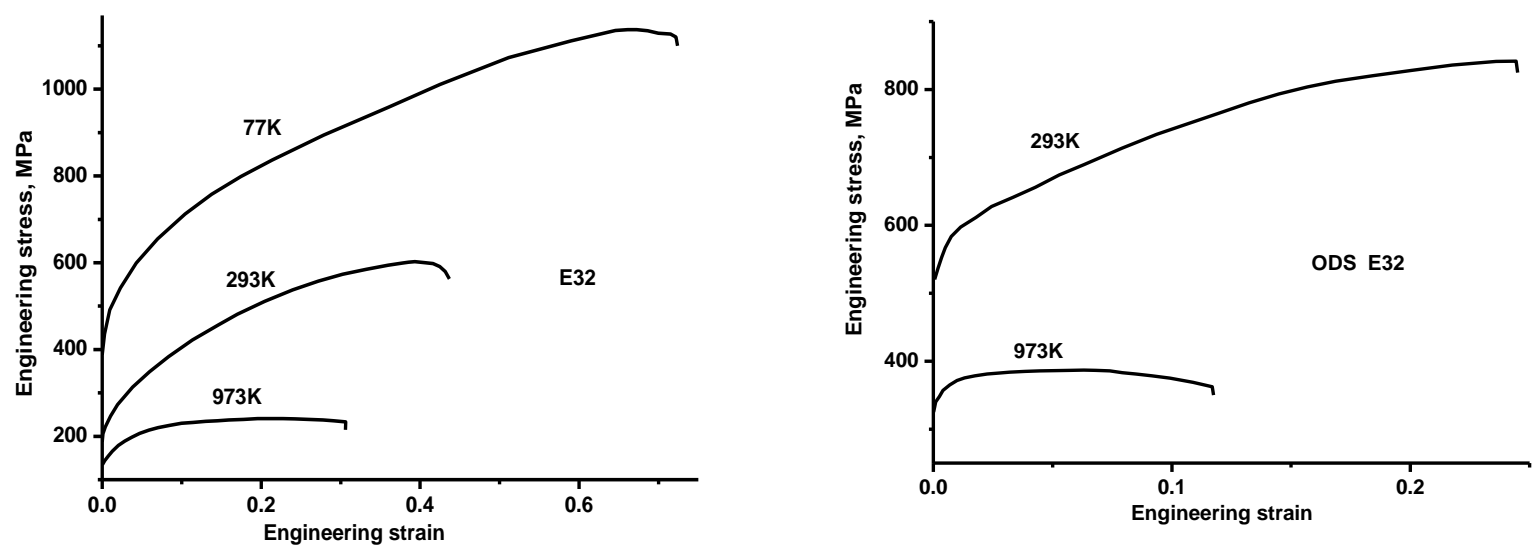

Fig. 7. Stress-strain diagrams of high-entropy alloys E32 and ODS E32 at different temperatures

Table 3

Mechanical properties of E32 and ODS E32 HEAs at different temperatures

\begin{tabular}{|c|c|c|c|c|c|c|c|c|c|}
\hline \multirow{3}{*}{ Alloy } & \multicolumn{4}{|c|}{$\sigma_{0.2}, \mathrm{MPa}$} & \multicolumn{4}{c|}{$\sigma_{\mathrm{B}}, \mathrm{MPa}$} & \multicolumn{4}{c|}{$\delta, \%$} \\
\cline { 2 - 11 } & \multicolumn{9}{|c|}{ Test temperature } \\
\cline { 2 - 10 } & $77 \mathrm{~K}$ & $293 \mathrm{~K}$ & $973 \mathrm{~K}$ & $77 \mathrm{~K}$ & $293 \mathrm{~K}$ & $973 \mathrm{~K}$ & $77 \mathrm{~K}$ & $293 \mathrm{~K}$ & $973 \mathrm{~K}$ \\
\hline E32 & 388 & 187 & 135 & 1137 & 602 & 241 & 72.5 & 44 & 31 \\
\hline ODS E32 & & 520 & 325 & & 842 & 387 & & 24.5 & 12 \\
\hline
\end{tabular}

Different patterns of the surface fracture were obtained after tensile tests of HEAs depending on the composition and microstructure of the alloys.

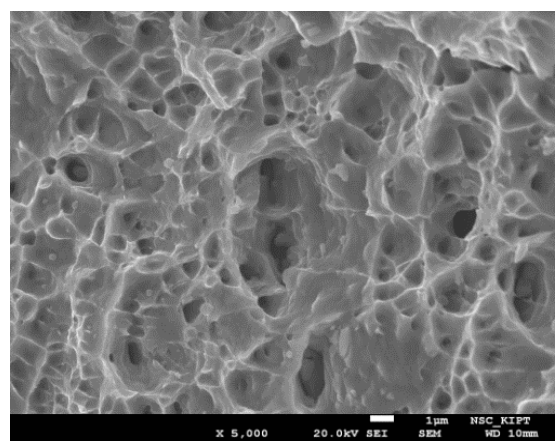

E3

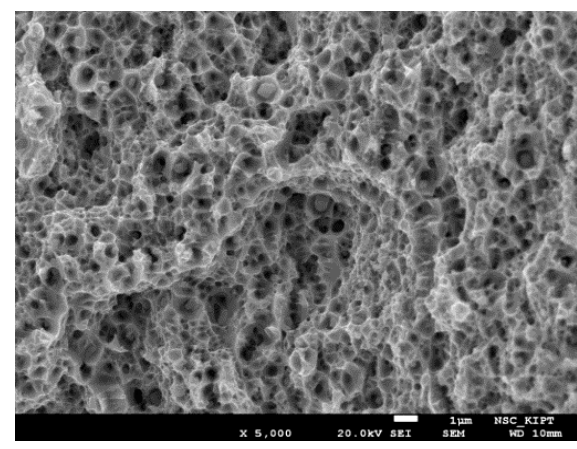

ODS E3

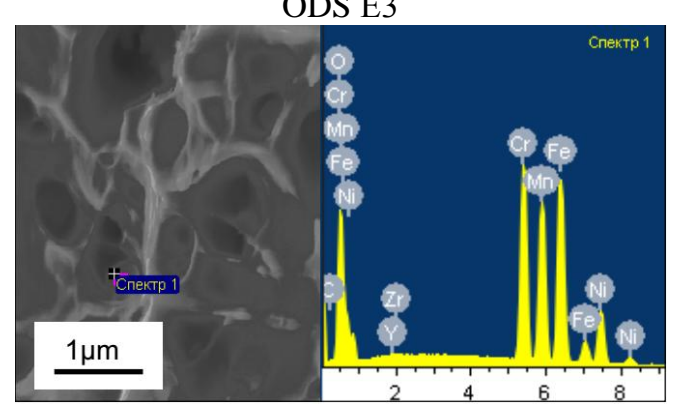

Corresponding fractograms of the fractured samples after tensile tests at temperature of $293 \mathrm{~K}$ are shown in Fig. 8.

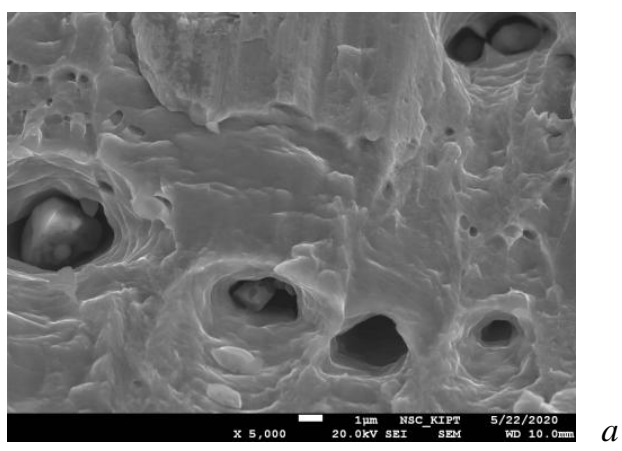

E32

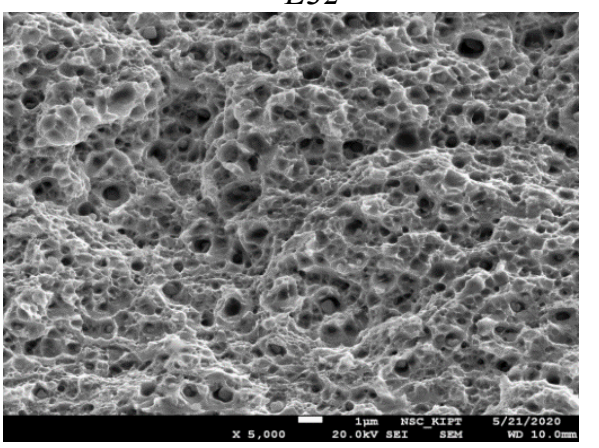

ODS E32

\begin{tabular}{|c|c|c|}
\hline & wt.\% & at.\% \\
\hline O K & 12.10 & 32.23 \\
\hline Cr K & 22.52 & 18.45 \\
\hline Mn K & 20.21 & 15.67 \\
\hline Fe K & 30.36 & 23.16 \\
\hline Ni K & 13.80 & 10.02 \\
\hline Y L & 0.26 & 0.12 \\
\hline Zr K & 0.75 & 0.35 \\
\hline
\end{tabular}

Fig. 8. Fractograms of HEAs tapes after mechanical tests at $293 \mathrm{~K}$ 
Analyzing the difference in the structure of the fracture surfaces, it can be noted that presence of oxide precipitates of micron size (see Fig. 8,a) plays significant role in the initial alloys. Such precipitates are almost always present in these alloys [16], but, according to the authors, do not significantly affect their mechanical characteristics. These precipitates, observed in the middle of the pits, play a significant role in initiating the material fracture processes. In E32 alloy there are fewer such precipitates but their size is larger than that in E3 alloy (see Fig. 8,a). Therefore, the nature of the fracture surface in these alloys is considerably different. For HEAs E3 and especially E32 in the initial state on the fracture surface next to the microrelief of the pit structure there are surfaces of smooth delamination, which are smooth, structureless surface areas with waved elements. The formation of such surfaces is associated with intense preliminary plastic deformation and faster crack propagation in comparison with pit fracture.

The fracture surfaces of ODS HEAs E3 and E32 (see Fig. 8,b) show pit character and indicate a high density of oxide precipitates of submicron size, on which pits are formed. Exactly the high density of such precipitates determines the refinement of the pit relief. A large number of small pits on the fracture surface, which are observe for both ODS HEAs E3 and E32, corresponds to a high degree of oxide strengthening. Small but sufficiently deep pits indicate a combination of high strength and toughness; the uniformity of the pit relief indicates a uniform distribution of submicron oxide particles.

As can be seen the fracture in the studied ODS alloys takes place mainly on the surface of the "particlematrix", which indicates a reduced level of cohesion of the particles with the matrix. Therefore, separate particles are often observed in the pits on the fracture surface. Analysis of these particles, performed in point mode, showed that the chemical composition of the particles differs from the matrix and corresponds to complex oxides (see Fig. 8,c). Moreover, as previously assumed, just $\mathrm{Cr}$ and $\mathrm{Mn}$ atoms with large atomic radii included in the composition of the oxides, which could affect the decrease in the lattice parameter of the matrix phase.

\section{CONCLUSIONS}

Oxide dispersion-strengthened HEAs CoCrFeMnNi and $\mathrm{CrFe}_{2} \mathrm{MnNi}$ were obtained by mechanical alloying. The size spectrum of oxide precipitates for studied alloys is characterized by the presence of both small precipitates $\sim 10 \mathrm{~nm}$, which are characteristic for ODS steels, and larger particles $(50 \ldots 150 \mathrm{~nm})$. The density of oxide precipitates is near $\sim 10^{21} \mathrm{~m}^{-3}$.

The composition of the oxides includes not only $\mathrm{Y}$ and $\mathrm{Zr}$, but also the matrix elements of the alloys, mainly $\mathrm{Cr}$ and $\mathrm{Mn}$.

Studies of the mechanical properties of the obtained ODS HEAs showed that the yield stress of those alloys increased by 2 times compared to the initial state, the ultimate strength practically did not change, and plasticity at $293 \mathrm{~K}$ was about $20 . .30 \%$.
A similar character of the microstructure and close values of mechanical characteristics make it possible to prefer non-cobalt ODS E32 HEA as a possible candidate for nuclear energy applications.

\section{ACKNOWLEDGEMENTS}

This work was prepared within the project № 2020.02/0327 "Fundamental aspects of the new materials creation with unique physical, mechanical and radiation properties based on the concentrated multicomponent alloys", implemented with the financial support of the National Research Foundation of Ukraine.

\section{REFERENCES}

1. T. Okuda, M. Fujiwara. Dispersion behavior of oxide particles in mechanically alloyed ODS steel // Journal of Materials Science Letters. 1995, v. 14 p. $1600-1603$.

2. D.T. Hoelzer, B.A. Pint, I.G. Wright. A microstructural study of the oxide scale formation on ODS Fe-13Cr steel // J. Nucl. Mater. 2000, v. 283-287, p. $1306-1310$

3. S. Ukai, M. Fujiwara. Perspective of ODS alloys application in nuclear environments // J. Nucl. Mater. 2002, v. 307-311, p. 749-757.

4. C. Cayron, E. Rath, I. Chu, S. Launois. Microstructural evolution of $\mathrm{Y}_{2} \mathrm{O}_{3}$ and $\mathrm{MgAl}_{2} \mathrm{O}_{4}$ ODS EUROFER steels during their elaboration by mechanical milling and hot isostatic pressing // J. Nucl. Mater. 2004, v. 335, p. 83-102.

5. T.-K. Kim, C.-S. Bae, D.-H. Kim, J. Jang, S.-H. Kim, C.-B. Lee, and D. Hahn. Microstructural observation and tensile isotropy of an austenitic ODS steel // Nuclear Engineering and Technology. 2008, v. $40, \mathrm{~N} 4$, p. $305-310$.

6. D.A. Mcclintock, M.A. Sokolov, T.D. Hotlzer, R.K. Nanstad. Mechanical properties of irradiated ODSEUROFER and nanocluster strengthened 14YWT // J. Nucl. Mater. 2009, v. 392, p. 353-359.

7. A.N. Velikodnyi, V.N. Voyevodin, M.A. Tikhonovsky, V.V. Bryk, A.S. Kalchenko, S.V. Starostenko, I.V. Kolodiy, V.S. Okovit, A.M. Bovda, L.V. Onischenko, G.Ye. Storogilov. Structure and properties of austenitic ODS steel 08Cr18Ni10Ti // PAST. 2014, N 4(92), p. 94-102.

8. J.W. Yeh, S.K. Chen, S.J. Lin, J.Y. Gan, T.S. Chin, T.T. Shun, C.H. Tsau, and S.Y. Chang. Nanostructured high-entropy alloys with multiple principal elements: novel alloy design concepts and outcomes // Adv. Eng. Mater. 2004, v. 6, p. 299-303.

9. B. Cantor, I.T.H. Chang, P. Knight, and A.J.B. Vincent. Microstructural development in equiatomic multicomponent alloys // Mater. Sci. Eng. A. 2004, v. 375-377, p. 213-218.

10. J.W. Yeh, S.Y. Chang, Y.D. Hong, S.K. Chen, S.J. Lin. Anomalous decrease in X-ray diffraction intensities of $\mathrm{CuNiAlCoCrFeSi}$ alloy systems with multi-principal elements // Mater. Chem. Phys. 2007, v. 103 , p. $41-46$.

11. K.Y. Tsai, M.H. Tsai, J.W. Yeh. Sluggish diffusion in CoCrFeMnNi high-entropy alloys // Acta Mater. 2013, v. 61, p. 4887-4897. 
12. D.B. Miracle, et al. Exploration and development of high entropy alloys for structural applications // Entropy. 2014, v. 16, p. 494-525.

13. Z. Li, K.G. Pradeep, Y. Deng, D. Raabe, C.C. Tasan. Metastable high-entropy dual-phase alloys overcome the strength-ductility trade-off // Nature. 2016, v. 534 , p. $227-230$.

14. O.N. Senkov, J.M. Scott, S.V. Senkova, D.B. Miracle, C.F. Woodward. Microstructure and room temperature properties of a high-entropy TaNbHfZrTi alloy // J. Alloys Compd. 2011, v. 509, p. 6043-6048.

15. F. Otto, A. Dlouhy, C. Somsen, H. Bei, G. Eggeler, E.P. George. The influences of temperature and microstructure on the tensile properties of a CoCrFeMnNi high-entropy alloy // Acta Mater. 2013, v. 61, p. 5743-5755.

16. B. Gludovatz, A. Hohenwarter, D. Catoor, E.H. Chang, E.P. George, R.O. Ritchie. A fractureresistant high-entropy alloy for cryogenic applications // Science. 2014, v. 345, p. 1153-1158.

17. J. Bae, J. Moon, J.M. Ji, D. Yim, D. Kim, S. Lee, H.S. Kim. Trade-off between tensile property and formability by partial recrystallization of CrMnFeCoNi high-entropy alloy // Mater. Sci. Eng. A. 2017, v. 703, p. 324-330.

18. Y. Liu, J. Wang, Q. Fang, B. Liu, Y. Wu, S. Chen. Preparation of superfine-grained high entropy alloy by spark plasma sintering gas atomized powder // Intermetallics. 2016, v. 68, p. 16-22.

19. S.H. Joo, H. Kato, M.J. Jang, J. Moon, E.B. Kim, S.J. Hong, H.S. Kim. Structure and properties of ultrafine-grained $\mathrm{CoCrFeMnNi}$ high-entropy alloys produced by mechanical alloying and spark plasma sintering // J. Alloys Compd. 2017, v. 698, p. 591-604.

20. Mayur Vaidya, Garlapati Mohan Muralikrishna, Budaraju Srinivasa Murty. High-entropy alloys by mechanical alloying. A review // Journal of Materials Research. 2019, v. 34, issue 5, p. 664-686.
21. M.A. Tikhonovsky, V.N. Voyevodin, A.N. Velikodnyi, A.S. Kalchenko, I.V. Kolodiy, S.V. Starostenko, V.S. Okovit. Microstructure and mechanical properties of austenitic ODS steel and ODS high entropy alloy // European Commission funded International workshop "Materials resistant to extreme conditions for future energy systems", 12-14 June 2017, Kyiv, Ukraine, p. 94.

22. H. Hadraba, Z. Chlup, A. Dlouhy, F. Dobes, P. Roupcova, M. Vilemova, J. Matejicek. Oxide dispersion strengthened $\mathrm{CoCrFeNiMn} \mathrm{high-entropy}$ alloy // Materials Science and Engineering: A. 2017, v. 689 , p. 252-256.

23. B. Jia, X.J. Liu, H. Wang, et al. Microstructure and mechanical properties of $\mathrm{FeCoNiCr}$ high-entropy alloy strengthened by nano- $\mathrm{Y}_{2} \mathrm{O}_{3}$ dispersion // Sci. China Tech. Sci. 2017, p.60-64.

24. B. Gwalani, R.M. Pohan, O.A. Waseem, T. Alam, S.H. Hong, H.J. Ryu, R. Banerjee. Strengthening of $\mathrm{Al}_{0.3} \mathrm{CoCrFeMnNi}$-based ODS high entropy alloys with incremental changes in the concentration of $\mathrm{Y}_{2} \mathrm{O}_{3} / /$ Scripta Materialia. 2019, v. 162 , p. $477-481$.

25. G.D. Tolstolutskaya, G.Y. Rostova, V.N. Voyevodin, A.N. Velikodnyi, M.A. Tikhonovsky, G.N. Tolmachova, A.S. Kalchenko, R.L. Vasilenko, I.E. Kopanets. Hardening of Cr-Fe-Ni-Mn high entropy alloys caused by the irradiation with argon ions // Problems of Atomic Science and Technology. Series "Physics of Radiation Effect and Radiation Materials Science”. 2017, N 5(111), p. 40-47.

26. В.М. Федірко, В.М. Воєводін, О.М. Великодний, М.А. Тихоновський, І.С. Кухар, Х.Р. Мельник. Вплив дисперсійного зміцнення нанооксидами на корозійну тривкість у розплавах свинцю високоентропійних сплавів системи $\mathrm{Cr}-\mathrm{Fe}-\mathrm{Mn}-\mathrm{Ni} / /$ Фізико-хімічна механіка матеріалів. 2019, №4, с. 6368 .

Статья поступила в редакциию 12.03.2021 2.

\section{МИКРОСТРУКТУРА И МЕХАНИЧЕСКИЕ СВОЙСТВА ДИСПЕРСНО-УПРОЧНЕННЫХ ОКСИДАМИ ВЫСОКОЭНТРОПИЙНЫХ СПЛАВОВ СоCrFeMnNi И СrFe $\mathrm{CnNi}_{2}$}

\section{И.В. Колодий, А.Н. Великодный, М.А. Тихоновский, В.Н. Воеводин, А.С. Кальченко,}

Р.Л. Василенко, В.С. Оковит

Методом механического легирования с последующим компактированием и спеканием получены высокоэнтропийные сплавы $\mathrm{CoCrFeMnNi}$ и $\mathrm{CrFe}_{2} \mathrm{MnNi}$, дисперсно-упрочненные предварительно синтезированными нанооксидами состава $80 \% \mathrm{Y}_{2} \mathrm{O}_{3}+20 \% \mathrm{ZrO}_{2}$ (мол.\%). Средний размер зерен в дисперсно-упрочненных сплавах составил примерно 2 мкм. Оксидные выделения в сплавах характеризуются наличием мелких частиц со средним размером около 10 нм и плотностью $\approx 10^{21} \mathrm{M}^{-3}$, а также незначительного количества больших частиц с размерами $50 \ldots 150$ нм. Установлен качественный состав частиц разного размера. Исследованы механические свойства сплавов при разных температурах. Показано, что прочностные характеристики значительно повышаются при упрочнении сплавов нанооксидными частицами.

\section{МІКРОСТРУКТУРА ТА МЕХАНІЧНІ ВЛАСТИВОСТІ ДИСПЕРСНО-ЗМНЦЕНИХ ОКСИДАМИ ВИСОКОЕНТРОПІЙНИХ СПЛАВІВ СоCrFeMnNi I CrFe $\mathrm{CHnNi}_{2}$}

\section{І.В. Колодій, О.М. Великодний, М.А. Тихоновський, В.М. Воєводін, О.С. Кальченко,}

\section{Р.Л. Василенко, В.С. Оковіт}

Методом механічного легування 3 наступним компактуванням та спіканням отримано високоентропійні сплави $\mathrm{CoCrFeMnNi}$ та $\mathrm{CrFe}_{2} \mathrm{MnNi}$, що зміцнені попередньо синтезованими нанооксидами складу $80 \% \mathrm{Y}_{2} \mathrm{O}_{3}+20 \% \mathrm{ZrO}_{2}(\%$ мол). Середній розмір зерен у дисперсно-зміцнених сплавах близько 2 мкм. Оксидні виділення в сплавах характеризуються присутністю дрібних часток з середнім розміром близько 10 нм і щільністю $\approx 10^{21} \mathrm{M}^{-3}$, а також незначної кількості більших часток з розмірами 50...150 нм. Встановлено якісний склад часток різного розміру. Досліджені механічні властивості сплавів при різних температурах. Показано, що міцнісні характеристики суттєво підвищуються при зміцненні сплавів нанооксидними частками. 